\title{
Zenet, an endangered language variety in Southern Algeria
}

\author{
Bachir Bouhania \\ Department of English, University of Adrar, Adrar, Algeria
}

Email address:

bouhania@yahoo.fr

\section{To cite this article:}

Bachir Bouhania. Zenet, an Endangered Language Variety in Southern Algeria. International Journal of Language and Linguistics. Special Issue: The Sociolinguistics of a Changing World. Vol. 2, No. 6-2, 2014, pp. 6-9. doi: 10.11648/j.ijll.s.2014020602.12

\begin{abstract}
In the Tuat, southern Algeria, Arabic is the major language variety; whereas, Zenet is a minor dialect neither taught at school nor promoted at the societal level. The objective of the present paper is to give a glimpse about the sociolinguistic changes that are underway in the Tuat, such as the actual position of Zenet at the institutional and societal levels, through objective measurements such as the national census, the school, and the radio programs. The paper focuses on the recent developments underwent by Zenet at the Radio of Adrar since 2006. This variety of Tamazight is witnessing an evolution in the program schedules and frequencies of broadcast, but no noticeable changes on the educational and the social levels. Hence, Zenet may be considered as an endangered language variety, since it does not receive governmental and institutional supports nor any local encouragement and promotion.
\end{abstract}

Keywords: Arabic, Endangered Language, Zenet, Tuat, Algeria, Adrar Radio, Vitality of Languages

\section{Introduction}

The recent developments underwent by Zenet at the Radio of Adrar show that this variety of Tamazight is witnessing an evolution. Yet, this progress is not noticeable on the educational and societal levels. Through objective measurements, the present research highlights the fact that Zenet is a minor language variety, which needs official as well as social promotions to be maintained within the local verbal repertoire. The investigation draws data from the national census, the archives of local radio broadcast system, and the educational curricula.

\section{Sociolinguistic Factors}

The contact between Arabic and Zenet reflects the connection of a majority group, the Arabs, with a minority group, the Zenets. Culture, which is an essential criterion for the vitality of both Arabic and Zenet, may have an impact on the society's bias towards one language variety and not the other depending on the status of each. On the other hand, the prestige of the speakers, which is tightly linked to their economic and social importance within the society, affects the status and vitality of their mother-tongue.

Institutional support is also another important issue in upholding the vitality of language both at the formal and informal representations. It means encouraging the use of language in formal institutions like the government, the mass-media, the religious services, and the economic sectors.

The social status factor, on the other side, is based on the speech community's perception of the role and importance of the language varieties concerned. It refers to the people's attitudes towards language that differ according to their social evaluation of the varieties of language present on the area (Fasold 1984:148; Edwards1982:20).

In the 1990's Tamazight became an official language of Algeria. Consequently, the balance and intergroup relations between the 'power' group and the submitted minorities started to change (Le Page and Tabouret-Keller, 1985), since the language was institutionally promoted through an academy (Haut Commissariat à l'Amazighité), the massmedia, and the school. Nowadays, the Zenet speakers are trying to revive their native language varieties through culture, folklore and the mass-media (the radio).This enables them to regain their lost status as a significant stratum of the local hierarchy and as an important ethnolinguistic group.

\section{Ethnolinguistic Groups}

Giles, Bourhis and Taylor (1977:308) define an 'ethnolinguistic group' as “... that which makes a group behave as a distinctive and active collective entity in intergroup situations". The latter definition applies to both Arabs and Zenets who differentiate between themselves at 
the socio-cultural and linguistic levels.

In the Tuat, vitality of Arabic and Zenet is an utmost priority for the natives. As claimed by Hamers and Blanc "the higher the vitality the more likely a group and its language(s) are to survive as a distinctive entity" (1989:163). The continued existence and survival of both Arabic and Zenet depend on social, cultural and educational factors that either inhibit or encourage the group's vitality (Harwood, Giles, and Bourhis 1994; Kristiansen, Harwood, and Giles 1991).

Objective vitality can be measured through objective data such as the demographic, social and political characteristics of the speakers, the institutional support of the language varieties and their domains of use. Subjective vitality relates to the speakers' own perception of their native language compared to others within the same speech community (Williams, 1973). As part of objective vitality, the next section introduces the institutional supports available for Arabic and Zenet, i.e.: Arabisation, formal school, and the radio.

\section{Arabisation in the Tuat}

Arabisation is the Algerian language planning and language policy (LP) that aimed at regaining the status of Arabic after the French colonisation. It sought to advance Arabic to the level of a national language, and to promote its use at all levels of education, as well as in the governmental services and ministries (Gallagher 1964:134, in Sirles 1999:118).

In southern Algeria, the informal-school system of the Zawayas (Holy shrines and Quranic schools) helps in implementing Arabisation. Their support of Arabic as the language of the Quran and of a literary heritage facilitates the implementation of Arabisation at the local level. On the other hand, the southerners' use of Arabic is an expression of nationalist feelings and the retention of one's own identity. Arabisation, then, is both iconic and symbolic for the southerners. Tuat post-independence youngsters are already acquainted with Arabic, since they attend the Zawayas at an early age.

\section{Education and Illiteracy-Eradication Programs}

Since independence, the government implements primary, intermediate, and secondary schools throughout the whole Wilaya (district) of Adrar to eradicate illiteracy and to spread compulsory education. As an example, the National Census of 1998 reports that, in the whole district, the percentages of illiterate males and females are $38.79 \%$. In 2001, the numbers decrease to $35.75 \%$, particularly in Adrar and Timimoun, the two most important cities. However, in the Zenet speaking Ksours (villages) the percentage of illiterates remains the highest.

After independence, both men and women attend
Illiteracy-eradication programs. Their motivation is stimulated by social and individual reasons (Ammon, 2002:315), for competence in Arabic offers future prospects to both sexes.

Illiteracy-eradication programs and Quranic schools are among the many factors that facilitate Arabisation in the Tuat However, they neither encourage the codification, nor the elaboration and implementation of Zenet. Actually, both Zenet and Tamachek are not taught at school, but are broadcast in the radio of Adrar.

\section{The Mass-Media}

In 2006, the Algerian government took the decision to spread the news to all layers of society through their ancestral mother-tongues, and to implement the local parlances and idioms through the radio, the television, the newspapers, and education. Since then, Adrar broadcasting network started to transmit the news reports in Zenet and Tamachek once a day.

Nowadays, $30 \%$ of Adrar radio programs are transmitted in Zenet and Tamachek equally. They vary between daily news bulletins, to interactive series with phone-in callers, to sociocultural releases dealing with patrimonies and cultural heritage of Zenets and Tuaregs of the Gurara-Tuat-Tidikelt. Some programs are illustrated in Table1:

Table 1. Titles of Zenet radio programs in Adrar broadcasting system

\begin{tabular}{|c|c|c|}
\hline Title & Year & Time \\
\hline 'An eye on the society' & 2006-2012 & $\begin{array}{l}\text { Tuesdays } \\
4 \text { to } 5 \mathrm{pm}\end{array}$ \\
\hline 'What we got' & 2010-2012 & $\begin{array}{l}\text { Mondays } \\
4 \text { to } 5 \mathrm{pm}\end{array}$ \\
\hline 'Our religion' & 2006-2012 & Weekly 4 to $5 \mathrm{pm}$ \\
\hline 'Greetings' & 2004-2012 & $\begin{array}{l}\text { Thursdays } \\
4 \text { to } 5 \mathrm{pm}\end{array}$ \\
\hline 'Stay with us' & 2010-2012 & $\begin{array}{l}\text { Sundays } \\
4 \text { to } 5 \mathrm{pm}\end{array}$ \\
\hline 'From our reality' & 2010-2012 & $\begin{array}{l}\text { Fridays } \\
4 \text { to } 5 \mathrm{pm}\end{array}$ \\
\hline 'Greetings and melodies' & 2008-2012 & $\begin{array}{l}\text { Weekly } \\
4 \text { to } 5 \mathrm{pm}\end{array}$ \\
\hline 'the light of Islam' & 2010-2012 & $\begin{array}{l}\text { Weekly } \\
4 \text { to } 5 \mathrm{pm}\end{array}$ \\
\hline
\end{tabular}

The radio, then, upholds and promotes Zenet. It also prevents its shift and disappearance. On the other hand, Zenet radio programs represent the only one institutional support of the latter language variety at the regional level. Their impact may be evaluated through the ethnolinguistic vitality felt by the speakers themselves.

\section{Ethnolinguistic Vitality of Arabic and Zenet}

To test the ethnolinguistic vitality of Arabic and Zenet, the Subjective Ethnolinguistic Vitality Questionnaire (SEVQ) of Bourhis, Giles and Rosenthal (1981) (based on Giles, Bourhis and Taylor, 1977) is used. This technique assesses and evaluates the influence of socio-structural variables on 
intergroup relations, second/foreign language learning and language maintenance. It also allows for a clearer appreciation of the speech community's attitudes towards the various language varieties.

In the present research, SEVQ measures the vitality of Arabic (MSA) and Zenet in the Tuat speech community. The questionnaires are distributed to and filled in by random samples of secondary school pupils and university students. The participants are both male and female, aged 16 to 20 year-old.

The young people are sensitive to the contention that characterizes the majority and the minority with regard to their positive or negative social identities. They have clear attitudes towards the vitality of the language varieties in opposition within their speech community.

The SEVQ addresses questions like:

-What is the vitality of Arabic and Zenet according to the speakers' school level and sex?

-What is the vitality of Arabic and Zenet at home and when addressing old people?

\section{The Sample}

The sample of the University of Adrar (U.A) consists of students from the department of English; whereas, the pupils come from three different secondary schools: Balkin II (B II, Adrar), El-Maghili (ELM, Adrar), and Fenoughil (FSC, Middle-Tuat). The word 'Arabic' means MSA in formal contexts and situations, and refers to the local variety in informal domains of language use. The sample breakdown is:

$\begin{array}{llll}\text { Institutions } & \text { boys } & \text { Girls } & \text { Total } \\ \text { U. Adrar } & 15 & 29 & 44 \\ \text { Balkin II } & 43 & 43 & 86 \\ \text { El-Maghili } & 50 & 49 & 99 \\ \text { Fenoughil } & 54 & 42 & 96 \\ \text { Total } & 162 & 163 & 325\end{array}$

\section{Analysis of the Questionnaires}

The results of the questionnaires inform about students' and pupils' sociolinguistic attitudes towards both local parlances, Arabic and Zenet. The results split into two parts. The first reports the participants' perceptions of the vitality of Arabic and Zenet when addressing old people and at home. The second part reports on the scores of both students and pupils' perceptions of the vitality of Arabic and Zenet in accordance with their geographical background and gender.

\subsection{Vitality of Arabic and Zenet with Interlocutors and at Home}

Students and pupils have the same tendencies as concerns language use with interlocutors. They address old people in Arabic or Zenet, depending on the addressee's mother-tongue. The difference, however, is in matter of frequency of use of both language varieties.

The students admit using Zenet with old women more than with old men. They account for this by stating that, in the Tuat, old women do neither attend formal nor informal schools. They speak Zenet from birth; for that reason, their grand children address them in their ancestral mother- tongue. Tables 2 and 3 report the results:

Table 2. Students' scores concerning the vitality of Arabic and Zenet when addressing old people

\begin{tabular}{llll}
\hline Students & Arabic & Zenet & No answers \\
\hline Old man & 79.41 & 17.64 & 2.94 \\
Old woman & 75 & 22.22 & 2.77 \\
\hline
\end{tabular}

Table 3. Pupils' scores concerning the vitality of Arabic and Zenet when addressing old people

\begin{tabular}{llll}
\hline Pupils & Arabic & Zenet & No answer \\
\hline old man & 86.51 & 5.61 & 7.86 \\
old woman & 81.11 & 6.66 & 12.22 \\
\hline
\end{tabular}

The pupils do not use Zenet as frequently as the students. They prefer to talk to their elders in the majority's mother tongue, Arabic. The scores show that the young people's insignificant use of Zenet and preference for Arabic is a sociolinguistic attitude towards the two original language varieties.

Table 4. Vitality of Arabic and Zenet at home according to Students' and pupils

\begin{tabular}{llll}
\hline home & Arabic & Zenet & Total \% \\
\hline Pupils & 92 & 8 & 100 \\
students & 94,18 & 5,81 & 100 \\
\hline
\end{tabular}

Table 4 makes it clear that the young adults and the children prefer to speak Arabic at home. It also shows that Zenet is seldom used ( $8 \%$ for the pupils vs. $5.81 \%$ for the students) in the same domain. The percentages of Table 4 verify those of Table 2 and 3, for they confirm that the young speakers use their original mother-tongue, Zenet, at home with old people, only.

\subsection{Vitality of Arabic and Zenet According to Location and Gender}

As far as location is concerned, Zenet is used in the Gurara, only. Table 5 illustrates the fact that the young speakers who use Zenet at home and with old people are not from the Tuat and the Tidikelt areas. They are Zenet speakers from the Gurara region.

Table 5. Use of Arabic and Zenet by location

\begin{tabular}{llll}
\hline Locations & Arabic $(\boldsymbol{\%})$ & Zenet $(\boldsymbol{\%})$ & Total \\
\hline Gurara & 76,19 & 23,8 & 100 \\
Tuat & 100 & 0 & 100 \\
Tidikelt & 100 & 0 & 100 \\
\hline
\end{tabular}

As a variable, sex of speaker is significant, for gender may be a cause of a sociolinguistic change in progress. The girls, for instance, make use of Zenet more than the boys. However, the scores attest that the young females' use of Zenet is not as important as that of Arabic (6.77\% vs. 93.22\%). Table 6 reports the scores in percentages: 
Table 6. Use of Arabic and Zenet according to sex of speaker

\begin{tabular}{llll}
\hline & Arabic & Zenet & Total \\
\hline Boys & 96.29 & 3.7 & 100 \\
Girls & 93.22 & 6.77 & 100 \\
\hline
\end{tabular}

\section{Conclusion and Discussion}

The research concludes that, in the Tuat, the youngsters have different perceptions of the ethnolinguistic vitality of Arabic and Zenet. Depending on the speech situation, location, and sex of speaker the young people show various tendencies of language use.

The most significant result is that the young speakers tend towards the majority's language, Arabic, instead of the original mother-tongue, Zenet, even in the Gurara. They also make use of that ancestral idiom just to address old people at home.

On the other hand, the institutional support of Zenet at the local radio broadcasting system is not enough to promote it. Zenet native speakers have to uphold and encourage its use at home as a means of everyday communication and domestic interaction. More than that, the local authorities and cultural spheres need to codify Zenet and implement it by creating informal schools as a first step, then formal schools and formal curricula later.

The final conclusion is that the young people's attitudes towards Zenet and Arabic are clear illustrations of their shift towards the majority's language at the expense of that of the minority. The end result is the death of Zenet if no societal and governmental efforts are undertaken to prevent its loss (Fishman 1991 and 2001; Fishman, Ferguson and Das Gupta 1968).

\section{References}

[1] Ammon, U. 2002. [Review of R. B. Kaplan and R. B. Baldauf. 1997. Language Planning from Practice to Theory. Multilingual Matters 108. Clevedon: Multilingual Matters.] Language problems and language Planning 263: 315-339. John Benjamins Publishing Company.

[2] Bourhis, R.Y., H.Giles and D.Rosenthal. 1981. Notes on the Construction of a 'Subjective Vitality Questionnaire' for Ethnolinguistic Groups. Journal of Multilingual and Multicultural Development 2(2):145-155.
[3] Edwards, J.R. 1982. Language attitudes and their implications. In E.B Ryan, and H. Giles (eds.), Attitudes towards Language Variation. London: Edward Arnold.

[4] Fasold, R.W. 1984. The Sociolinguistics of Society. Oxford: OUP.

[5] Fishman, J.A. 1991. Reversing Language Shift: theoretical and Empirical foundations of Assistance to Threatened Languages. Clevedon: Multilingual Matters.

[6] Fishman, J.A. 2001. Can Threatened Languages be saved? Reversing Language Shift, Revisited: A $21^{\text {st }}$ Century Perspective. Clevedon: Multilingual Matters

[7] Fishman, J.A., C.A.Ferguson, and J. Das Gupta (Eds.) 1968. Language Problems of Developing Nations. John Wiley \& Sons, Inc.: New York.

[8] Gallagher, C.F. 1964. North African problems and prospects: language and identity. In J.A.Fishman, C.A. Ferguson, and J. Das Gupta (eds.) Language Problems of Developing Nations. New York: Wiley and Sons, Inc. pp.129-150.

[9] Giles, H., R.Y. Bourhis and D.M. Taylor 1977. Towards a theory of language in ethnic group relations. In Howard Giles (Ed.), Language, Ethnicity, and Intergroup Relations. New York: Academic Press.

[10] Hamers, J.F. and M.H.A. Blanc, 1989. Bilinguality and Bilingualism. Cambridge: CUP.

[11] Harwood, J., H.Giles and R.Y.Bourhis 1994. The Genesis of Vitality Theory: Historical Patterns and Discoursal Dimensions. Int'l.J.Soc.Lang. 108:167-206.

[12] Kristiansen, T., J.Harwood, and H.Giles.1991. Ethnolinguistic Vitality in 'The Danish capital of America'. Journal of Multilingual and Multicultural development 12(6):421-448.

[13] Le Page, Robert B. 1980. 'Projection, Focussing, Diffusion'. In Robert B. LePage and M.W.S. Da Silva (eds.) York Papers in Linguistics 9. York: Department of Language, University of York.

[14] Le Page, Robert B., and Andrée Tabouret-Keller. 1985. Acts of Identity: Creole-based Approaches to Language and Ethnicity. Cambridge: CUP.

[15] Sirles, C. 1999. Politics and Arabization: the evolution of postindependence North Africa. Int'1.J.Soc.Lang. 137:115-129.

[16] Williams, F. 1973. Some research notes on dialect attitudes and stereotypes. In Roger W. Shuy and Ralph W. Fasold (eds.), Language Attitudes: Current Trends and Prospects. Georgetown University Press, Washington, D.C. 